\title{
PENGARUH PARTISIPASI ANGGARAN DAN MDTIVASI TERHADAP KINERJA PEGAWAI PADA PT. BANK MANDIRI KCP MMU MEDAN PASAR GAMBIR
}

\author{
Amran Manurung' \\ Fakultas Ekonomi Universitas HKBP Nommensen, Medan \\ amran.sdkknnsultan国gmail.com', triiaktavianasaragihh回gmail.com²
}

\begin{abstract}
Info Artikel
Diterima: 13 Maret 2020

Revisi : 17 April 2020

Terbit : : 20 Juni 2020
\end{abstract}

\section{Key words:}

Budget Participation, Employee

Perfarmance and Work

Motivation

\section{Kata Kunci:}

Partisipasi Anggaran,

Kinerja Pegawai Dan

Motivasi Kerja

\section{Corresponding Author :}

Amran Manurung, E-mail : amran.sdkkonsultan回gmail.com

Abstract

This research was conducted to measure whether budgetary participation and motivation affect employee perfarmance in banking either partially or simultaneously. The research sample was 33 people, where the sample was selected by saturated sampling method. Based on the results of data analysis and testing described in the previous chapter, some conclusions obtained fram this study include: (I) Partially, budget participation has a pasitive and insignificant effect on the perfarmance of employees of PT. Bank Mandiri KСР MMU Medan Pasar Gambir with a regression coefficient of 0.015 and a data significance of 0.946; (2) Partially, mativation has a pasitive and insignificant effect on the performance of employees of PT. Bank Mandiri KCP MMU Medan Pasar Gambir with a regression coefficient of 0.320 and a data significance of 0. प5I. This indicates that employees' high motivation to work will achieve a predetermined standard / goal; (3) Simultaneously, budget participation and motivation together have a significant effect on the performance of employees of PT. Bank Mandiri КСР MMU Medan Pasar Gambir where the value of the Simultaneous Test Caefficient $(F)$ is 35,272 with a data significance of Q,0००. This means that participation rates and work mativation can affect employee performance results.

Abstrak

Penelitian ini dilakukan untuk menguji apakah partisipasi anggaran dan mativasi berpengaruh terhadap kinerja pegawai pada perusahaan perbankan baik secara parsial maupun simultan. Sampel penelitian ini sebanyak 33 arang, dimana sampel dipilih dengan metade sampling jenuh. Berdasarkan hasil analisis data dan pengujian hipatesis yang telah diuraikan pada bab sebelumnya, beberapa kesimpulan yang diperoleh dari penelitian ini antara lain : (I) Secara parsial, Partisipasi anggaran berpengaruh positif dan tidak signifikan terhadap kinerja pegawai PT. Bank Mandiri КСР МMU Medan Pasar Gambir dengan nilai Koefisien Regresi sebesar 0,015 dan signifikansi data sebesar 0,946 ;(2) Secara parsial, Motivasi berpengaruh positif dan tidak signifikan terhadap kinerja pegawai PT. Bank Mandiri КСР MMU Medan Pasar Gambir dengan nilai Kaefisien Regresi Sebesar 0,320 dan signifikansi data sebesar 0,051. Hal ini menunjukkan bahwa motivasi pegawai yang tinggi dalam bekerja akan mencapai suatu standar/tujuan yang telah ditetapkan ; (3) Secara simultan, Partisipasi anggaran dan motivasi secara bersama-sama

Pengaruh Partisipasi Anggaran Dan Mativasi Terhadap Kinerja Pegawai Pada Pt. Bank Mandiri KCP MMU 


\section{PENDAHULUAN}

berpengaruh signifikan terhadap kinerja pegawai PT. Bank Mandiri КСР MMU Medan Pasar Gambir dimana nilai dari Kaefisien Uji Simultan (F) adalah sebesar 35,272 dengan signifikansi data sebesar 0,000. Artinya bahwa ketika partisipasi anggaran dan motivasi kerja, dapat mempengaruhi hasil kinerja pegawai.

Perkembangan perusahaan yang semakin meningkat pesat mengakibatkan semakin meluasnya usaha yang berada dalam jangkauannya. Meluasnya unit usaha dalam perusahaan menuntut pihak manajemen untuk menentukan orang-orang tertentu yang mampu bersedia diberi tanggung jawab dalam pengelolaan unit usaha tersebut. Dalam lingkungan persaingan glabal, perusahaan dituntut untuk dapat memuaskan pelanggan (custamer). Sehingga seluruh kegiatan perusahaan dituntut untuk berfakus kepada customer satisfaction. Manajemen menggunakan anggaran dalam pengelolaan perusahaan. Anggaran digunakan oleh manajemen sebagai alat perencanaan dan pengendalian kegiatan. Dengan dilibatkannya karyawan dalam proses penyusunan anggaran, hal ini akan membuat komitmen pada karyawan bahwa anggaran yang ada juga merupakan tujuannya.

Penyusunan anggaran yang baik harus menggunakan prinsip dari bawah ke atas (bottom up) yang melibatkan berbagai level jabatan di setiap departemen dalam suatu perusahaan. Hal ini akan menjadi lebih baik karena dapat mengharapkan berbagai masukan dari kalangan bawahan untuk menentuan target kinerjanya yang hendak ingin dicapai dalam suatu periode atau jangka waktu tertentu. Penyusunan anggaran semacam ini merupakan pendekatan anggaran partisipatif. Partisipasitif adalah suatu proses pengambilan keputusan bersama aleh dua bagian atau lebih pihak dimana keputusan tersebut akan memiliki dampak masa depan terhadap mereka yang membuatnya. Dengan kata lain pegawai dan manajer tingkat bawah memiliki suara dalam proses manajemen.

Dalam perusahaan, kinerja searang karyawan dihubungkan dengan partisipasinya dalam penyusunan anggaran. Partisipasi dalam penyusunan anggaran merupakan tingkat seberapa besar keterlibatan dan pengaruh manajer dalam proses penyusunan anggaran dalam suatu departemen atau bagiannya baik secara periodik maupun tahunan.

Permasalahan akan muncul apabila anggaran dipandang sebagai suatu yang tidak rasional dan bersifat memaksa pelaksana anggaran. Hal ini akan membawa beberapa dampak yang tidak diinginkan dalam pelaksanaan fungsi anggaran seperti rasa tidak percaya diri (distrust), penolakan (resistence), konflik internal, dan hal-hal yang tidak diinginkan. Dengan demikian dapat disimpulkan bahwa sikap pelaksana anggaran (karyawan pada manajemen tingkat bawah dan menengah) dalam perusahaan memegang peranan penting dalam pencapaian tujuan perusahaan. Pencapaian tujuan perusahaan dipengaruhi kuat oleh tujuan pribadi karyawan perusahaan. Sesearang akan terdarang untuk melakukan sesuatu bila dirasakan ada kebutuhan pada dirinya yang menuntut 
untuk dipenuhi. Mativasi adalah suatu matif dorangan,ketekunan, dan intensitas berhubungan dengan seberapa giat sesearang berusaha. Ini adalah elemen yang paling banyak mendapat perhatian ketika kita membicarakan tentang mativasi. Prosestimbulnya motivasi sesearang merupakan gabungan dari kansep kebutuhan, dorangan,tujuan dan imbalan. Motivasi merupakan derajat sampai sejauhmana individu ingin dan berusaha dalam mengerjakan suatu pekerjaan dengan baik dan upaya yang tinggi kearah tujuan organisasi akan dikandisikan oleh upaya untuk memenuhi kebutuhan individual. Namun, intensitas yang tinggi sepertinya tidak akan menghasilkan prestasi kerja yang memuaskan kecuali upaya tersebut dikaitkan dengan arah yang menguntungkan arganisasi. Dengan demikian, kita harus mempertimbangkan kualitas serta intensitas upaya secara bersamaan. Individuindividu yang termativasi bertahan melakukan suatu tugas dalam waktu yang cukup lama demi mencapai tujuan mereka. Dleh sebab itu, kebutuhan akan mempengaruhi perilaku sesearang sampai kebutuhan tersebut terpenuhi. Apabila kebutuhan pegawai tidak terpenuhi maka pegawai tersebut akan menunjukkan perilaku kecewa. Sebaliknya, jika kebutuhannya terpenuhi maka pegawai tersebut akan memperlihatkan perilaku yang gembira sebagai manifestasi dari rasa puasnya.

Dari pernyataan tersebut manusia mempunyai kebutuhan untuk diakui akan keberadaannya, dihargai dan perwujudan diri untuk menunjukkan prestasi terbaik dengan terlibat dalam prases pengambilan keputusan. Sesearang akan merasakan bahwa keputusan yang mereka ambil bersama adalah juga keputusannya, maka timbulrasa bertanggung jawab dalam melaksanakan keputusan tersebut dan akan memicu untuk mencapai kinerja yang memuaskan. Dengan demikian jelas bahwa berpartisipasi dalam penyusunan anggaran akan memberikan kepuasan diri dan diharapkan terbentuk sikap yang positif terhadap pelaksana anggaran. Sikap pasitif berarti anggaran dipandang sebagai suatu rencana yang ditetapkan secara rasional dan disertai komitmen untuk mencapainya.

Dengan adanya partisipasi anggaran dapat memberikan penilaian bagaimana mativasi karyawan dalam melakukan pekerjaannya dan akan mempengaruhi kinerja yang dihasilkan untuk mencapai tujuan dalam suatu instansi perbankan. Berdasarkan uraian di atas, partisipasi anggaran mempunyai peranan penting dalam mempengaruhi mativasi dan meningkatkan kinerja pegawai PT. Bank Mandiri КСР Medan Pasar Gambir. Partisipasi anggaran yang telah ditetapkan diharapkan dapat memberikan kinerja yang baik agar terealisasi penggunaan secara tepat, dan membangkitkan motivasi intern para pegawai yang bekerja di PT. Bank Mandiri КСР Medan Pasar Gambir.

Adanya partisipasi anggaran, akan meningkatkan tanggungjawab serta kinerja dari manajer level bawah dan menengah. Manajer dapat memberikan ide-ide kreatif yang dimilikinya kepada manajer atas, dalam mencapai tujuan perusahaan. Dari adanya keikutsertaan para manajer level menengah dan bawah dalam 
penentuan anggaran, maka akan didapatkan keputusan yang lebih realistis sehingga tercipta pencapaian tujuan perusahaan yang lebih besar.

Dalam penyusunan anggaran, bawahan diberi kesempatan untuk berpartisipasi. Hal ini dilakukan untuk mengantisipasi kecenderungan timbulnya sikap agresi bawahan terhadap manajemen (atasan) dan timbulnya ketegangan yang mengakibatkan inefisiensi. Dengan melibatkan bawahan, tujuan yang diinginkan perusahaan akan lebih dapat diterima, karena anggata arganisasi dapat bersama-sama mendiskusikan pendapat mereka mengenai tujuan tersebut dan terlibat dalam menentukan langkah-langkah untuk mencapai tujuan tersebut.

Menurut Kusuma, Moheri dan Arifah, Setyorini, Dianawati dan Ghozali dalam Pipit Fitri Rahayu : "Pengaruh Partisipasi Anggaran berpengaruh pasitif dan signifikan terhadap kinerja karyawan maupun perusahaan".

Sedangkan menurut Supono dan Indriantoro dalam Pipit Fitri Rahayu: "Menunjukkan hasil tidak mendukung adanya hubungan positif diantara pengaruh partisipasi penganggaran terhadap kinerja karyawan". Dengan adanya perbedaan pendapat antara penelitian terdahulu, makapenelitian ini bertujuan untuk menguji kembali pengaruh partisipasi anggaran dan motivasi terhadap kinerja pegawai di bidang perbankan.

\section{METODE PENELITIAN}

\section{Populasi Dan Sampel}

Populasi dari penelitian ini adalah seluruh karyawan PT. Bank Mandiri КСР MMU Medan Pasar Gambir yang bekerja. Penentuan populasi ini diharapkan mampu mempresentasikan populasi yang lebih besar, sehingga hasil penelitian ini dapat digeneralisasikan dengan baik. Sampel dalam penelitian ini adalah karyawan yang terkait dalam partisipasi penyusunan anggaran yang berdasarkan jumlah karyawan yang berjumlah 33arang yang diambil dari semua divisi.

Peneliti mengambil sampel berdasarkanyang ada pada semua bagian karena semua bagian tersebut yang dapat memberikan informasi yang berkaitan dengan partisipasi anggaran dan motivasi terhadap kinerja karyawan pada PT. Bank Mandiri KСР MMU Medan Pasar Gambir.

\begin{tabular}{|l|c|}
\hline \multicolumn{1}{|c|}{ Bidang } & Jumlah \\
\hline Kepala cabang & 1 \\
\hline Divisi Branch Dperation Supervisar & 3 \\
\hline Divisi Mikro Banking Manager & 1 \\
\hline Divisi Analisis Kredit & 4 \\
\hline Divisi Customer Service & 2 \\
\hline
\end{tabular}




\begin{tabular}{|l|c|}
\hline Teller & 2 \\
\hline Divisi Asuransi & 3 \\
\hline Divisi Marketing Kredit & 5 \\
\hline Divisi Collection & 2 \\
\hline Divisi Teknologi Informasi & 4 \\
\hline Divisi Helper & 5 \\
\hline Branch Business Control & 1 \\
\hline Jumlah Populasi & 33 \\
\hline
\end{tabular}

Sumber: PT. Bank Mandiri КСР MMU Medan Pasar Gambir

\section{Teknik Pengumpulan Data}

Teknik pengumpulan data yang digunakan dalam penelitian ini adalah teknik pengumpulan data melalui penelitian lapangan (metade survei).Metade yang mendukung dalam pengumpulan data guna melengkapi penelitian ini adalah kuisioner. Dalam penelitian ini penulis mengajukan pernyataan secara tertulis. Data dikumpulkan melalui metade kuesioner dimana dengan penyebaran daftar pertanyaan (kuesioner) tersebut akan dijawab oleh respanden. Skala pengukuran yang digunakan peneliti yaitu Skala Likert dimana responden menyatakan tingkat setuju atau tidak setuju atas pernyataan yang diajukan secara tertulis oleh peneliti.

\section{Analisis Data}

Metode analisis yang digunakan untuk menguji hipotesis adalah analisis regresi berganda, karena ada dua variabel independen dan satu variabel dependen. Analisis regresi digunakan untuk mengetahui besarnya pengaruh partisipasi anggaran dan mativasi terhadap kinerja pegawai PT.Bank Mandiri КСР Medan Pasar Gambir.

\section{HASIL DAN PEMBAHASAN}

Pengaruh Partisipasi Anggaran terhadap Kinerja Pegawai PT.Bank Mandiri KCP MMU Medan Pasar Gambir

Hasil penelitian ini menunjukkan bahwa partisipasi anggaran berpengaruh pasitif dan tidak signifikan terhadap kinerja pegawai PT Bank Mandiri KСP MMU Medan Pasar Gambir dengan nilai thitung sebesar Q,068 sedangkan nilai ttabel adalah 2,039 atau secara sederhana diketahui bahwa 0,068 < 2,039 dan nilai signifikansi 0,946 > $\alpha=$ 0,05. Maka, hl ditolak dan h0 diterima, dapat disimpulkan bahwa partisipasi anggaran berpengaruh positif dan tidak signifikan, artinya jika partisipasi anggaran ditingkatkan akan menghasilkan kinerja pegawai yang baik dan hubungan partisipasi anggaran terhadap kinerja pegawai sangat baik. Hasil penelitian ini mendukung hasil penelitian yang dilakukan oleh Hafridebri (2006), dimana penelitian tersebut meneliti tentang 
pengaruh partisipasi anggaran terhadap kinerja manajerial pada perusahaan manufaktur di Pekanbaru. Hasil penelitiannya menunjukkan bahwa partisipasi anggaran terbukti berpengaruh signifikan positif terhadap kinerja manajerial di perusahaan manufaktur.

\section{Pengaruh Motivasi Kerja terhadap Kinerja Pegawai PT.Bank Mandiri КГР ММU Medan Pasar Gambir}

Berdasarkan hasil penelitian ini menunjukkan bahwa motivasi kerja berpengaruh pasitif dan tidak signifikan terhadap kinerja pegawai PT. Bank Mandiri KС MMU Medan Pasar Gambir dengan nilai ttabel = 2,039 sedangkan nilai dari thitung adalah sebesar 2,028 nilai signifikansi 0,05I > $\alpha=$ 0,05, maka HI ditolak dan HD diterima. Hal ini dapat disimpulkan bahwa semakin tinggi motivasi kerja, maka kinerja pegawai PT. Bank Mandiri КСР MMU Medan Pasar Gambir juga akan semakin meningkat. Tingkat kemampuan akan dapat mempengaruhi hasil kinerja pegawai dimana semakin tinggi tingkat kemampuan pegawai akan menghasikan kinerja yang semakin tinggi pula. Faktor lain adalah motivasi kerja yaitu dorangan dari dalam pegawai untuk melakukan suatu pekerjaan. Dengan adanya motivasi kerja yang tinggi pegawai akan terdorang untuk melakukan suatu pekerjaan sebaik mungkin yang akan mempengaruhi hasil kinerja. Semakin tinggi motivasi yang dimiliki semakin tinggi pula kinerja yang dapat dihasilkan. Hasil penelitian ini mendukung hasil penelitian yang dilakukan oleh Ngurah Bagus Dhermawan (2012) dimana penelitian ini meneliti tentang pengaruh mativasi, lingkungan kerja terhadap kinerja pegawai pada Kantar Dinas Pekerjaan Umum Pravinsi Bali. Responden penelitiannya ialah pegawai satuan kerja terbukti berpengaruh positif namun tidak signifikan terhadap kinerja pegawai pada Kantor Dinas Pekerjaan Umum Provinsi Bali

\section{Pengaruh Partisipasi Anggaran dan Motivasi Secara Bersama- Sama terhadap Kinerja Pegawai PT.Bank Mandiri KCP MMU Medan Pasar Gambir}

Berdasarkan pengujian yang telah dilakukan maka diketahui bahwa nilai Fhitung sebesar 35,272 dengan tingkat signifikansi data adalah sebesar Q,०००. Hasil ini menunjukan bahwa partisipasi anggaran dan motivasi secara bersama-sama mempengaruhi kinerja pegawai. Dengan demikian bahwa partisipasi anggaran dan mativasi secara simultan berpengaruh signifikan terhadap kinerja pegawai PT.Bank Mandiri KᄃP MMU Medan Pasar Gambir.Suatu tujuan/standar yang dirancang secara partisipatif disetujui oleh pimpinan, maka pegawai akan bersungguh-sungguh dalam tujuan/standar yang telah ditetapkan dan pegawai juga memiliki rasa tanggung jawab pribadi untuk mencapainya karena ikut serta terlibat dalam penyusunannya. Tingkat kemampuan dapat mempengaruhi hasil kinerja pegawai dimana semakin tinggi tingkat kemampuan pegawai dengan motivasi yang benar akan menghasilkan kinerja yang semakin tinggi.Hasil Penelitian ini mendukung hasil penelitian yang dilakukan oleh Fiesta Andriani (2018) dimana penelitian ini meneliti tentang pengaruh partisipasi anggaran dan 
mativasi terhadap kinerja pegawai kantor DPRD Sumatera Utara. Hasil penelitiannya menunjukkan bahwa partisipasi anggaran dan motivasi berpengaruh pasitif dan signifikan terhadap kinerja pegawai DPRD Sumut.

\section{KESIMPULAN}

Memperhatikan hasil pengujian deng an menggunakan Model Regresi Linier Berganda pada pragram SPSS Versi 20, maka kesimpulan yang dapat diambil dari penelitian mengenai "Pengaruh Partisipasi Anggaran dan Motivasi terhadap Kinerja Pegawai PT. Bank Mandiri KCP MMU Medan Pasar Gambir adalah sebagai berikut:

I. Secara parsial, Partisipasi anggaran berpengaruh pasitif dan tidak signifikan terhadap kinerja pegawai PT. Bank Mandiri KCP MMU Medan Pasar Gambir dengan nilai Koefisien Regresi sebesar 0,015 dan signifikansi data sebesar 0,946. Hal ini menunjukkan bahwa HI ditalak dan HD diterima dikarenakan Thitung <Ttabel, yaitu 0,068 < 2,039 dan nilai signifikansi 0,946 > 0, प5. Yang berarti bahwa pegawai memiliki partisipasi anggaran yang baik dalam menyusun anggaran yang akan meningkatkan kinerja pegawai. Dimana semakin aktif pegawai ikut serta dalam partisipasi anggaran, maka kinerja pegawai PT. Bank Mandiri КСР MMU Medan Pasar Gambir juga akan semakin meningkat.

2. Secara parsial, Motivasi berpengaruh positif dan tidak signifikan terhadap kinerja pegawai PT. Bank Mandiri KСP MMU Medan Pasar Gambir dengan nilai Koefisien Regresi Sebesar 0,320 dan signifikansi data sebesar 0,051. Hal ini menunjukkan bahwa HI ditalak dan HO diterima dikarenakan Thitung < Ttabel yaitu 2,028 < 2,039 dengan nilai signifikansi 0,051 > 0,05. Sehingga motivasi pegawai yang tinggi dalam bekerja akan mencapai suatu standar/tujuan yang telah ditetapkan sehingga kinerja yang dihasilkan meningkat dari sebelumnya. Maka kinerja pegawai PT. Bank Mandiri KᄃP MMU Medan Pasar Gambir akan semakin meningkat.

3. Secara simultan, Partisipasi anggaran dan mativasi secara bersama-sama berpengaruh signifikan terhadap kinerja pegawai PT. Bank Mandiri КСР MMU Medan Pasar Gambir dimana nilai dari Koefisien Uji Simultan (F) adalah sebesar 35,272 dengan signifikansi data sebesar 0,000. Artinya bahwa ketika partisipasi anggaran dan mativasi kerja, dapat mempengaruhi hasil kinerja pegawai dimana semakin tinggi tingkat kemampuan pegawai dengan motivasi yang benar akan menghasilkan kinerja yang semakin tinggi.

4. Nilai pengaruh dari variabel bebas yaitu Partisipasi Anggaran dan Mativasi terhadap Kinerja Pegawai dapat di ukur dengan melihat hasil dari Kaefisien Determinasi. Nilai R Square sebesar 0,702 dinyatakan baik, variable Partisipasi Anggaran dan Mativasi sebagai variable bebas, dapat menjelaskan sebesar 70,2\% terhadap variable Y yaitu Kinerja Pegawai sebagai variable terikat. 
Sedangkan sisanya sebesar 29,8\% akan dijelaskan oleh variabel-variabel lainnya, diluar dari variable penelitian yang mampu mempengaruhi nilai variable terikat.

\section{DAFTAR PUSTAKA}

Hasibuan, H Malayu, Manajemen Sumber Daya Manusia, Edisi Ke Tiga Belas: Bumi Aksara, Jakarta, 2009.

Huda, Syamsul Andi, Pengaruh Partisipasi Dalam Penyusunan Anggaran dan Mativasi Terhadap

Kinerja

Karyawan pada PT. Bank Mega TBK Cabang Pinrang, Skripsi, Fakultas Ekonomi dan Bisnis, Universitas Hasanuddin, 2013

Sinambela, Lijan, Metadalagi Penelitian Kuantitatif, Graha IImu. Yagyakarta, 2014

Mangkunegara, Anwar Prabu, Manajemen Sumber Daya Manusia, Cetakan Kesebelas: PT Remaja Rasdakarya, Bandung, 2018

Prawinegor a, Darsona dan Ari Purwanti, Akuntansi Manajemen, Edisi Ketiga: Mitra Wicana Media, Jakarta, 2009

Rahayu, Pipit Fitri, Pengaruh Partisipasi Penyusunan Anggaran, Komitmen Drganisasi, dan Profesionalisme Terhadap Kinerja Manajerial Bank BUMN Kata Palembang, Jaurnal of Business Administration, Vol 3, № 2, 2019

Rusliaman, dkk, Pengantar Bisnis. Universitas HKBP Nommensen Medan, Medan, 2019

Sanjaya, Muhammad Taufiek Ria, Pengaruh Disiplin Kerjadan Mativasi Kerja Terhadap Kinerja Karyawan pada Hotel Ras In Yogyakarta. Skripsi, Fakultas Ekonami Universitas Negeri Yagyakarta, 2015

Silaban, Adanan, dan Meilinda Harefa, Sistem Pengendalian Manajemen: Universitas HKBP Nommensen Medan, Medan, 2017

Sugiyana, Metade Penelitian Kuantitatif Kualitatif dan RED, Alfabeta, Bandung, 2016

Sutrisno, Edy, Manajemen Sumber Daya Manusia, Edisi Pertama: Prenamedia Graup, Jakarta, 2016

Suwanda, Diah Indriani dan Eddy Madiana Sutanta, Hubungan Lingkungan Kerja, D isiplin Kerja, dan Kinerja Karyawan. Jurnal Manajemen dan Kewirausahaan, $\quad$ Vol. 17 No 2, 2015 